\author{
수수 $x$ 수단그라스 교잡종 논토양 재배시 품종별 생육특성 및 \\ 사료가치 비교 연구 \\ 전병태 $^{1} \cdot$ 문상호 $^{1} \cdot$ 이상무 $^{2}$
}

\title{
A Comparative Studies on the growth Characteristics and Feed Components of Sorghum $x$ Sudangrass hybrids at Paddy Field Cultivation
}

\author{
Byong Tae Jeon ${ }^{1}$, Sang Ho Moon ${ }^{1}$ and Sang Moo Lee ${ }^{2}$
}

\begin{abstract}
This study was carried out to compare the agronomic characteristics, forage yield, and feed value of nine sorghum $\times$ sudangrass hybrids at paddy field cultivation. The nine recommended sorghum $\times$ sudangrass hybrids used in this study were P877F, Cow pow, Turbo gold, Maxi graze, Jumbo, G7, Sweet home, Honey chew BMR and Green star. Plant height, leaf number, stem diameter, and stem hardness were higher in Jumbo than other varieties $(\mathrm{P}<0.01)$. Sugar content (brix) was higher in order of $\mathrm{P} 877 \mathrm{~F}>$ Sweet home $>$ maxi graze $>$ Green star $>$ Cow pow $>$ G7 $(\mathrm{P}<0.01)$. Fresh $(86,199 \mathrm{~kg} / \mathrm{ha})$ and dry matter yield $(16,206 \mathrm{~kg} / \mathrm{ha})$ of Jumbo were higher than other varieties $(\mathrm{P}<0.01)$. Crude protein was the highest in Maxi graze $(6.5 \%)$, but crude fat was the highest in Honey chew BMR as $2.1 \%(\mathrm{P}<0.01)$. NDF and ADF of Jumbo and G7 were higher than other varieties $(\mathrm{P}<0.01)$. TDN was higher in order of Maxi graze $>$ Sweet home $>\mathrm{P} 877 \mathrm{~F}>$ Honey chew BMR $>$ Green star, but no significant differences were found among the varieties. Minerals were the highest in Cow pow $(15,020.5 \mathrm{mg} / \mathrm{kg})$, and Sweet home $(6,222.6 \mathrm{mg} / \mathrm{kg})$ was the lowest as compared to other varieties $(\mathrm{P}<0.01)$. Total amino acids were higher in order of Maxi graze $>$ Sweet home $>$ Turbo gold $>$ Honey chew BMR $>$ Jumbo $(\mathrm{P}<0.01)$.

Crude protein yield and crude fat yield were the highest in Turbo gold $(814.6 \mathrm{~kg} / \mathrm{ha})$ and Honey chew BMR (309.8kg/ha), respectively $(\mathrm{P}<0.01)$. Mineral yield was the highest in Cow pow as $207.6 \mathrm{~kg} / \mathrm{ha}$ $(\mathrm{P}<0.01)$. Amino acid yield $(592.2 \mathrm{~kg} / \mathrm{ha})$ and $\mathrm{TDN}$ yield $(10,194 \mathrm{~kg} / \mathrm{ha})$ were the highest in Sweet home. Based on the above results, sorghum $\times$ sudangrass hybrid varieties should be selected on the basis of the purpose of use. Because, each varieties showed various growth characteristics and nutrition yield (protein, fat, mineral, amino acid, TDN).
\end{abstract}

(Key words : Sorghum $\times$ sudangrass hybrid, TDN, Mineral, Amino-acid, Paddy field)

$\begin{array}{cl}\text { I. 서 론 } & \text { 가 늦어지고 옥수수 재배가 어려운 지역이나 } \\ & \text { 옥수수 병충해가 심한 지역에서는 하계작물로 } \\ & \text { 수수 및 수단그라스 계통을 청예 및 사일리용 }\end{array}$

${ }^{1}$ 건국대학교 녹용연구센터 (Korea Nokyoung Research Center, Konkuk University, 322 Danwol, Chungju, 380701, Korea)

2 경북대학교 축산BT학부(Faculty of Animal Science and Biotechnology, Kyungpook National University, Sangju-Si 742-711, Korea)

Corresponding author: Sang Moo Lee, Faculty of Animal Science and Biotechnology, Kyungpook National University, Sangju 742-711. Korea. Tel: +82-54-530-1224. E-mail: smlee0103@knu.ac.kr 
으로 많이 재배하고 있다(Lee, 2005a; Ji et al., 2010). 특히, 수수 $\times$ 수단그라스 교잡종은 종자가 전량 외국에서 수입되기 때문에 우리나라 기후 에 알맞은 품종을 선발하기 위하여 적응성, 수 량성 및 사료적 가치 검정 $(\mathrm{Kim}$ et al., 1991; Han et al., 1984; Jeon et al., 1989; Lee et al., 1994; Kim et al., 2002) 및 효율적인 재배관리를 위한 시험 (Seo and Kim, 1985; Lee et al., 1992; Lee et al., 2005a,b)들이 많이 행해지고 있다. 그 러나 수수 $\times$ 수단그라스 교잡종은 매년 육종 개 발된 다수성 품종이 도입되고 있기 때문에 지난 몇 년 동안 실행한 시험결과에 의존하여 품종을 선택 사용하는 것은 현실적으로 문제가 대두 되 고 있다. 또한 국내 연구는 대부분 생육특성 및 수량성에 국한 되어 품종을 검토하고 있고, 사 료가치에 관한 연구는 일반성분 및 $\mathrm{TDN}$ 가에 대한 검정으로 편중되어 있다. 그리고 최근 수 수 $\times$ 수단그라스 교잡종을 논토양에서 재배함에 따라 문제점으로 대두되고 있는 것은 대부분 1 차 예취 시 대형 트랙터를 이용하기 때문에 예 리하지 않은 예취 날에 의하여 잔주가 여러 갈 래로 쪼개지고 2차적으로는 트랙터의 무게에 의 하여 바퀴에 짓눌리는 현상이 나타난다. 이어서 기계화 추비에 따른 바퀴 짓눌림으로 재생하여 야 할 잔주들이 대부분 고사하는 경향이 높게 나타난다. 따라서 본 연구는 국내 수입 수수 $\times$ 수단그라스 교잡종을 논토양 재배 시 노동력 절 감 및 최대 건물 수확량을 확보할 수 있도록 유 도하기 위하여 1 회 수확을 목표로 재배기간을 105 일로 (조생종 옥수수 기준)하여 생육특성 및 영양소 수량을 조사하여 품종이 가지고 있는 다 양한 형질 및 화학적 성분의 특성을 상호 비교 검토하고 향후 수수 $\times$ 수단그라스 교잡종 품종을 논토양 재배 시 선발 활용할 수 있는 기초자료 를 제공하고자 실시하였다.

\section{ㅍ. 재료 및 방법}

본 시험은 논토양에서 2009년 5월부터 2009
년 8월까지 4개월간 수행하였으며, 공시품종은 2008년도 수입적응성시험 인증품종으로서 출수 형인 P877F, Maxigraze, Sweet home, Honey chew BMR 4품종, 비출수형인 Cow pow, Turbo gold, Jumbo, G7, Green star 5품종, 총 9품종을 난괴법 3 반복으로 하였다. 파종은 5 월 21 일에 실시하였으며 파종방법은 휴폭 $50 \mathrm{~cm}$ 주간거리 $5 \mathrm{~cm}$ 로 2립 점파하였다. 구당면적은 $3 \mathrm{~m} \times 4 \mathrm{~m}$ $=12 \mathrm{~m}^{2}$ 으로 하였으며 시비량은 ha당 질소, 인 산, 가리를 각각 $125,75,75 \mathrm{~kg}$ 를 전량 기비로 시용하였다. 예취는 사일리지용으로 활용하기 위하여 9월 3일 1회 예취하였다 (재배기간 105 일). 생육 기간 중 멸강충이 발생함에 따라 초 기에 엘산과 피리모수화제를 살포하였으며 잡 초제거는 인력제초를 실시하여 병충해 및 잡초 침입에 따른 피해주는 발생하지 않았다. 생육 조사는 농촌진흥청 $(\mathrm{RDA}, 2003)$ 농사시험 조사 기준에 준하여 실시하였으며, 생초수량은 중앙 2 열을 예취하여 조사하였다. 생육특성은 각 품 종별 6 열 중 중앙 1 열에서 목측으로 관측하여 가장 평균적인 것으로 생각되는 10 주를 반복별 로 선발하여 조사하였다. 그리고 각 품종 마다 반복별 5 주씩 선발하여 절단 한 후 $60^{\circ} \mathrm{C}$ 통풍 건조기 속에서 72 시간 건조 후 평량하여 건물 율을 구한 후 분쇄하여 분석시료로 사용하였 다. 경경도는 $\mathrm{KM}$ spring 경도계 (일본)를, 당도 는 PR 101 당도계 (일본)를 이용하여 반복별 5 주씩 예취 된 부위로부터 $10 \mathrm{~cm}$ 지점을 측정하 였다. 일반분석은 $\mathrm{AOAC}$ 법(1995)에 의하여 분 석하였으며 $\mathrm{ADF}$ 와 $\mathrm{NDF}$ 는 Goering과 Van Soest (1970)의 방법으로 분석하였다. TDN함량 은 $4.898+(89.796 \times \mathrm{NEL}), \quad \mathrm{NEL}=0.7936-(0.003$ $44 \times \mathrm{ADF})$ 공식을 이용하여 계산하였다 $(\mathrm{Kim}$ et al., 2009). 그리고 구성아미노산은 Automatic amino acid analyzer(Biochrom-30, Pharmacia Biotech Co., Swiss)로 분석하였으며, 이때 column 은 Na form column을 이용하였다. 무기물 성분 은 시료를 전처리한 후 $\mathrm{Ca}, \mathrm{Co}, \mathrm{Cu}, \mathrm{Fe}, \mathrm{K}$, $\mathrm{Mg}, \mathrm{Mn}, \mathrm{Mo}, \mathrm{Na}, \mathrm{Zn}, \mathrm{As}, \mathrm{Cd}, \mathrm{Cr}, \mathrm{Ni}, \mathrm{Pb}$ 등은 
Table 1. Monthly meteorological data during the experimental periods

\begin{tabular}{cccccc}
\hline Month & Day & $\begin{array}{c}\text { Mean temp. } \\
\left({ }^{\circ} \mathrm{C}\right)\end{array}$ & $\begin{array}{c}\text { Sunshine } \\
(\mathrm{hr})\end{array}$ & $\begin{array}{c}\text { Precipitation } \\
(\mathrm{mm})\end{array}$ & $\begin{array}{c}\text { Rainy days } \\
(\text { day })\end{array}$ \\
\hline \hline May & $1 \sim 31$ & 18.8 & 239.7 & 116.8 & 10 \\
June & $1 \sim 30$ & 22.5 & 199.4 & 47.8 & 10 \\
July & $1 \sim 31$ & 23.4 & 119.9 & 358.9 & 20 \\
August & $1 \sim 31$ & 23.8 & 129.4 & 104.7 & 9 \\
\hline
\end{tabular}

Table 2. Chemical properties of the soil before experiment

\begin{tabular}{|c|c|c|c|c|c|c|c|c|}
\hline \multirow{2}{*}{$\begin{array}{c}\mathrm{pH} \\
(1: 5)\end{array}$} & \multirow{2}{*}{$\begin{array}{l}\mathrm{OM} \\
(\%)\end{array}$} & \multirow{2}{*}{$\begin{array}{l}\mathrm{T}-\mathrm{N} \\
(\%)\end{array}$} & \multirow{2}{*}{$\begin{array}{c}\text { Av. } \mathrm{P}_{2} \mathrm{O}_{5} \\
(\mathrm{mg} / \mathrm{kg})\end{array}$} & \multicolumn{4}{|c|}{ Ex. cation $\left(\mathrm{cmol}^{+} \mathrm{kg}^{-}\right)$} & \multirow{2}{*}{$\begin{array}{c}\mathrm{CEC} \\
\left(\mathrm{cmol}^{+} \mathrm{kg}^{-}\right)\end{array}$} \\
\hline & & & & $\mathrm{K}$ & $\mathrm{Na}$ & $\mathrm{Ca}$ & $\mathrm{Mg}$ & \\
\hline 6.45 & 2.42 & 0.15 & 82.58 & 0.54 & 0.12 & 3.74 & 0.99 & 11.8 \\
\hline
\end{tabular}

ICP (Inductively Coupled Plasma, IRis Intrepid,

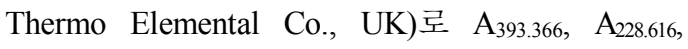
$\mathrm{A}_{324.754,} \mathrm{~A}_{259.940}, \mathrm{~A}_{766.491}, \mathrm{~A}_{285.213}, \mathrm{~A}_{257.610}, \mathrm{~A}_{202.030}$, $\mathrm{A}_{588.995}, \mathrm{~A}_{213.856}, \mathrm{~A}_{189.042}, \mathrm{~A}_{226.502}, \mathrm{~A}_{283.563}, \mathrm{~A}_{231.604}$, $\mathrm{A}_{220.353}$ 에서 각각 분석하였다. 분석조건은 approximate RF power가 $1,150 \mathrm{w}$ 이며, analysis pump rate는 $100 \mathrm{rpm}$, nebulizer pressure와 observation height는 각각 $30 \mathrm{psi}$ 및 $15 \mathrm{~mm}$ 로 하였다. 시험 결과의 평균값 및 표준오차는 SAS (Statistics analytical System, USA) program(2002)을 사용 하여 구하였고 Duncan의 다중검정 방법으로 $5 \%$ 및 $1 \%$ 수준에서 유의성 검정을 실시하였 다. 그리고 시험기간 동안 기상 조건은 Table 1 에서 보는 바와 같이 평년 조건과 비슷하였으 며, 토양조건 (Table 2)은 밭 토양에 비하여 유 기물 및 질소 함량은 높고 인산함량은 떨어지 는 토양이었다.

\section{III. 결과 및 고찰}

1. 수수 $\times$ 수단그라스 교잡종의 품종별 생육 특성 및 건물수량

공시 품종 중 P877F, Maxi graze, Sweet home 및 Honey chew BMR은 출수하였고 나머 지 5 품종은 출수가 되지 않았다. 수확 시 숙기
는 출수품종을 기준으로 볼 때 출수기 유숙기 에 해당되었다. 초장은 비출수형인 Jumbo가 $329.5 \mathrm{~cm}$ 로 가장 길었으며 Green star가 226.3 $\mathrm{cm}$ 로 가장 짧았다 $(\mathrm{P}<0.01)$. Lee 등 (1994)은 수 수 $\times$ 수단그라스 교잡종 9품종을 1 차 예취한 결 과 평균 초장은 $174.0 \sim 221.4 \mathrm{~cm}$, Chun 등 (1995) 은 품종별 2차 예취 시 $227.7 \sim 256.7 \mathrm{~cm}$ 범위를 나타냈다고 보고하였다. 그리고 Lee 등 (2000) 은 출수형에 비하여 비출수형이 초장이 길었다 고 보고하였으며, Lee 등 (1991)은 수수 $\times$ 수단 그라스 교잡종은 절간 신장기 동안은 수확시기 가 늦을수록 초장이 증가한다고 보고하였다. 이들 보고로 볼 때, 수수 $\times$ 수단그라스 교잡종 의 초장은 품종별, 재배기간, 예취회수 및 숙기 등에 따라 다양하게 나타나는 것을 알 수 있 다. 그러나 본 시험 결과에 나타난 초장은 다 른 실험에 비하여 초장이 길게 나타난 것은 재 배기간이 길었던 것이 원인으로 생각된다. 엽 장, 엽폭, 엽수는 각각 Honey chew $\mathrm{BMR}$, Green star 및 Jumbo가 다른 품종에 비하여 높 게 나타났다 $(\mathrm{P}<0.01)$. 고사엽 수는 $\mathrm{P} 877 \mathrm{~F}$ 가 2.9 엽으로 가장 높게 Maxi graze가 1.0 엽으로 가 장 낮게 나타났다. 경의 굵기와 경도에 있어서 는 Jumbo가 각각 $11.0 \mathrm{~mm}$ 와 $1.9 \mathrm{~kg} / \mathrm{cm}^{2}$ 으로 가 장 높았던 반면 Maxi graze와 Green star는 각 각 $6.9 \mathrm{~mm}$ 와 $0.5 \mathrm{~kg} / \mathrm{cm}^{2}$ 로 가장 낮은 수치를 보 
Table 3 . The growth characteristics and yield of sorghum $\times$ sudangrass hybrids

\begin{tabular}{|c|c|c|c|c|c|c|c|c|c|}
\hline \multirow[b]{2}{*}{ Items } & \multicolumn{9}{|c|}{ Varieties } \\
\hline & P877F & $\begin{array}{l}\text { Cow } \\
\text { pow }\end{array}$ & $\begin{array}{l}\text { Turbo } \\
\text { gold }\end{array}$ & $\begin{array}{l}\text { Maxi } \\
\text { graze }\end{array}$ & Jumbo & G7 & $\begin{array}{l}\text { Sweet } \\
\text { home }\end{array}$ & $\begin{array}{c}\text { Honey } \\
\text { chew } \\
\text { BMR }\end{array}$ & $\begin{array}{c}\text { Green } \\
\text { star }\end{array}$ \\
\hline Heading $(O, \times)$ & $\mathrm{O}$ & $x$ & $x$ & O & $x$ & $x$ & O & O & $x$ \\
\hline Maturity stage & milk & - & - & milk & - & - & milk & heading & - \\
\hline Plant height (cm) & $261.1^{\mathrm{CD}}$ & $264.1^{\mathrm{C}}$ & $271.7^{\mathrm{C}}$ & $230.9^{\mathrm{EF}}$ & $329.5^{\mathrm{A}}$ & $309.7^{\mathrm{B}}$ & $273.7^{\mathrm{C}}$ & $245.6^{\mathrm{DE}}$ & $226.3^{\mathrm{F}}$ \\
\hline Leaf length $(\mathrm{cm})$ & $74.9^{\mathrm{E}}$ & $98.6^{\mathrm{AB}}$ & $99.2^{\mathrm{AB}}$ & $85.0^{\mathrm{CD}}$ & $98.4^{\mathrm{AB}}$ & $98.8^{\mathrm{AB}}$ & $90.0^{\mathrm{BC}}$ & $103.1^{\mathrm{A}}$ & $79.9^{\mathrm{DE}}$ \\
\hline Leaf width $(\mathrm{cm})$ & $3.7^{\mathrm{AB}}$ & $3.6^{\mathrm{B}}$ & $3.4^{\mathrm{B}}$ & $3.4^{\mathrm{B}}$ & $4.9^{\mathrm{AB}}$ & $3.7^{\mathrm{AB}}$ & $3.9^{\mathrm{AB}}$ & $4.9^{\mathrm{AB}}$ & $5.2^{\mathrm{A}}$ \\
\hline Leaf number (No.) & $9.6^{\mathrm{B}}$ & $8.8^{\mathrm{B}}$ & $9.7^{\mathrm{B}}$ & $8.5^{\mathrm{B}}$ & $11.7^{\mathrm{A}}$ & $9.4^{\mathrm{B}}$ & $9.4^{\mathrm{B}}$ & $8.9^{\mathrm{B}}$ & $9.6^{\mathrm{B}}$ \\
\hline Dead leaf (No.) & $2.9^{\mathrm{A}}$ & $2.1^{\mathrm{AB}}$ & $1.2^{\mathrm{D}}$ & $1.0^{\mathrm{CD}}$ & $1.7^{\mathrm{BCD}}$ & $2.0^{\mathrm{BC}}$ & $1.9^{\mathrm{BC}}$ & $2.3^{\mathrm{AB}}$ & $2.1^{\mathrm{AB}}$ \\
\hline Stem diameter (mm) & $7.1^{\mathrm{CD}}$ & $8.0^{\mathrm{BCD}}$ & $8.0^{\mathrm{BCD}}$ & $6.9^{\mathrm{D}}$ & $11.0^{\mathrm{A}}$ & $7.9^{\mathrm{BCD}}$ & $9.5^{\mathrm{AB}}$ & $9.0^{\mathrm{BC}}$ & $7.4^{\mathrm{CD}}$ \\
\hline Stem hardness $\left(\mathrm{kg} / \mathrm{cm}^{2}\right)$ & $1.7^{\mathrm{A}}$ & $1.6^{\mathrm{AB}}$ & $1.3^{\mathrm{AB}}$ & $0.6^{\mathrm{C}}$ & $1.9^{\mathrm{A}}$ & $1.4^{\mathrm{AB}}$ & $1.5^{\mathrm{AB}}$ & $0.9^{\mathrm{BC}}$ & $0.5^{\mathrm{C}}$ \\
\hline Brix degree $\left(B^{\circ}\right)$ & $13.6^{\mathrm{A}}$ & $7.9^{\mathrm{B}}$ & $4.9^{\mathrm{C}}$ & $11.1^{\mathrm{A}}$ & $5.9^{\mathrm{BC}}$ & $7.1^{\mathrm{BC}}$ & $13.3^{\mathrm{A}}$ & $6.9^{\mathrm{BC}}$ & $8.2^{\mathrm{B}}$ \\
\hline Fresh yield (kg/ha) & $50,123^{\mathrm{F}}$ & $59,203^{\mathrm{DE}}$ & $71,005^{\mathrm{B}}$ & $40,712^{\mathrm{G}}$ & $86,199^{\mathrm{A}}$ & $66,124^{\mathrm{BC}}$ & $56,210^{\mathrm{E}}$ & $62,303^{\mathrm{CD}}$ & $42,245^{\mathrm{G}}$ \\
\hline DM yield (kg/ha) & $16,084^{\mathrm{A}}$ & $13,663^{\mathrm{C}}$ & $14,292^{\mathrm{BC}}$ & $11,781^{\mathrm{D}}$ & $16,206^{\mathrm{A}}$ & $15,294^{\mathrm{B}}$ & $16,029^{\mathrm{A}}$ & $14,753^{\mathrm{BC}}$ & $11,097^{\mathrm{D}}$ \\
\hline
\end{tabular}

$A, B, C, D, E, F$ Means in the row with difference superscripts different $(\mathrm{P}<0.01)$.

였다 $(\mathrm{P}<0.01)$. 품종별 당도 함량을 보면 $\mathrm{P} 877 \mathrm{~F}$

$>$ Sweet home $>$ Maxigraze $>$ Green star 순으

로 높게 나타났다 $(\mathrm{P}<0.01)$. Lee와 Lee (2010),

Smith (1972)는 일반적으로 사일리지 제조 시 하베스터로 수확하면 경경도는 큰 문제가 되지 않지만, 당도가 떨어지는 것은 사일리지 품질 에 영향을 미친다고 하였다.

생초수량은 Jumbo 품종이 $86,199 \mathrm{~kg} / \mathrm{ha}$ 로 가 장 많았으며, Maxi graze 품종이 $40,712 \mathrm{~kg} / \mathrm{ha}$ 로 서 가장 적은 수량을 나타냈다 $(\mathrm{P}<0.01)$. 그리고 건물수량에 있어서도 역시 Jumbo 품종이 $16,206 \mathrm{~kg} / \mathrm{ha}$ 로 높게 나타났다 $(\mathrm{P}<0.01) . \mathrm{Kim}$ 등 (1998)은 수단그라스계 잡종 11품종에 대하여 3 회 예취 시 건물수량은 평균 $13,818 \sim 17,555$ $\mathrm{kg} / \mathrm{ha}$ 범위 였다고 하였으며, Ji 등 (2010)은 Sorghum $\times$ Sudangrass 교잡종 10품종을 2회 예 취한 결과 건물수량은 $10,836 \sim 21,098 \mathrm{~kg}$ 범위였 다고 보고하였다. 이들의 보고와 본 실험에 있 어서 품종별 생산된 건물생산량 $(11,097$ 16,206 $\mathrm{kg} / \mathrm{ha}$ ) 범위와 비교 시 큰 차이가 나타나지 않 았다. 특히 Jumbo 품종이 가장 높은 생초 및 건물수량을 보였던 것은 다른 품종에 비하여
초장이 길고, 엽수가 많고, 경이 굵고 딱딱하였 던 것이 주원인으로 생각된다.

2. 수수 $\times$ 수단그라스 교잡종의 품종별 화학 적 성분

조단백질 함량은 품종별 $3.5 \sim 6.5 \%$ 범위로서 Maxi graze가 6.5\%로서 가장 높게 Cow pow가 $3.5 \%$ 로서 가장 낮은 함량치를 보였다 $(\mathrm{P}<0.01)$. $\operatorname{Lim}$ 등 (2006)은 논에서 수수 $\times$ 수단그라스 교 잡종 재배 시 화학비료와 액비를 살포한 결과, 1차 예취 시 3.9 6.6\%의 함량을 나타냈다는 보 고와 같은 경향치를 나타냈다.

그러나 Shin 등 (2005)은 간척지에서 수수 $\times$ 수단그라계 품종별 조단백질 함량은 1차 예취 시 6.60 9.81\% 범위 였다고 보고한 내용과는 다소 차이를 보였다. Jeon과 Lee (2005)는 수수 $\times$ 수단그라스계 잡종은 신장기부터 유숙기까지 는 조단백질 함량이 $9.1 \%$ 에서 $4.9 \%$ 까지 감소 한다는 보고로 볼 때, 예취시기에 따라 조단백 질 함량은 다르게 나타나는 것으로 판단된다. 조지방 및 조회분 함량은 각각 Honey chew 
Table 4. The chemical compositions of sorghum $\times$ sudangrass hybrids (DM. \%)

\begin{tabular}{|c|c|c|c|c|c|c|c|c|c|}
\hline \multirow[b]{2}{*}{ Items } & \multicolumn{9}{|c|}{ Varieties } \\
\hline & $\mathrm{P} 877 \mathrm{~F}$ & $\begin{array}{l}\text { Cow } \\
\text { pow }\end{array}$ & $\begin{array}{l}\text { Turbo } \\
\text { gold }\end{array}$ & $\begin{array}{l}\text { Maxi } \\
\text { graze }\end{array}$ & Jumbo & G7 & $\begin{array}{l}\text { Sweet } \\
\text { home }\end{array}$ & $\begin{array}{c}\text { Honey } \\
\text { chew } \\
\text { BMR }\end{array}$ & $\begin{array}{c}\text { Green } \\
\text { star }\end{array}$ \\
\hline Crude protein & $3.7^{\mathrm{EF}}$ & $3.5^{\mathrm{F}}$ & $5.7^{\mathrm{B}}$ & $6.5^{\mathrm{A}}$ & $4.0^{\mathrm{E}}$ & $4.6^{\mathrm{D}}$ & $4.7^{\mathrm{C}}$ & $4.5^{\mathrm{D}}$ & $4.7^{\mathrm{C}}$ \\
\hline Crude fat & $1.3^{\mathrm{D}}$ & $1.4^{\mathrm{D}}$ & $1.3^{\mathrm{D}}$ & $1.7^{\mathrm{C}}$ & $1.4^{\mathrm{D}}$ & $1.7^{\mathrm{C}}$ & $1.8^{\mathrm{BC}}$ & $2.1^{\mathrm{A}}$ & $1.9^{\mathrm{B}}$ \\
\hline Crude ash & $3.5^{\mathrm{H}}$ & $5.6^{\mathrm{C}}$ & $7.7^{\mathrm{A}}$ & $5.0^{\mathrm{D}}$ & $6.0^{\mathrm{B}}$ & $5.9^{\mathrm{B}}$ & $3.7^{\mathrm{G}}$ & $4.6^{\mathrm{E}}$ & $4.1^{\mathrm{F}}$ \\
\hline NDF & $67.5^{\mathrm{F}}$ & $74.1^{\mathrm{B}}$ & $74.7^{\mathrm{B}}$ & $65.4^{\mathrm{F}}$ & $76.1^{\mathrm{A}}$ & $76.1^{\mathrm{A}}$ & $69.3^{\mathrm{CD}}$ & $69.6^{\mathrm{CD}}$ & $70.7^{\mathrm{C}}$ \\
\hline $\mathrm{ADF}$ & $41.5^{\mathrm{D}}$ & $46.7^{\mathrm{B}}$ & $47.3^{\mathrm{B}}$ & $40.0^{\mathrm{D}}$ & $50.8^{\mathrm{A}}$ & $50.0^{\mathrm{A}}$ & $40.5^{\mathrm{D}}$ & $44.1^{\mathrm{C}}$ & $45.8^{\mathrm{B}}$ \\
\hline Crude fiber & $35.5^{\mathrm{F}}$ & $42.1^{\mathrm{C}}$ & $42.5^{\mathrm{C}}$ & $34.7^{\mathrm{G}}$ & $48.7^{\mathrm{A}}$ & $46.1^{\mathrm{B}}$ & $39.4^{\mathrm{E}}$ & $42.4^{\mathrm{C}}$ & $41.0^{\mathrm{D}}$ \\
\hline $\mathrm{TDN}$ & 63.3 & 61.7 & 61.6 & 63.8 & 60.5 & 60.7 & 63.6 & 62.5 & 62.0 \\
\hline
\end{tabular}

$\mathrm{A}, \mathrm{B}, \mathrm{C}, \mathrm{D}, \mathrm{E}, \mathrm{F}, \mathrm{H}$ Means in the row with difference superscripts different $(\mathrm{P}<0.01)$.

$\mathrm{BMR}$ 이 각각 $2.1 \%$ 와 $7.7 \%$ 로서 가장 높게 나타 났다 $(\mathrm{P}<0.01) . \mathrm{NDF}, \mathrm{ADF}$ 및 조섬유 함량은 Jumbo가 각각 $76.1,50.8$ 및 $48.7 \%$ 로 가장 높 게 나타났다 $(\mathrm{P}<0.01)$. 이와 같은 결과는 Jumbo 가 다른 품종에 비하여 경이 굵고, 경이 딱딱 한(경화) 것이 원인으로 생각된다. $\mathrm{TDN}$ 함량 은 Maxi graze > Sweet home > P877F > Honey chew BMR 순으로 높게 나타났지만 상 호 품종 간 유의적인 차이는 나타나지 않았다.

3. 수수 $\times$ 수단그라스 교잡종의 품종별 광물 질 성분

광물질은 시험 품종 모두 $\mathrm{K}>\mathrm{Ca}>\mathrm{Mg}$ 순 으로 높은 함량치를 나타났다. 먼저 가장 높은 함량을 나타낸 $\mathrm{K}$ 를 보면 Turbo gold가 7,796.0 $\mathrm{mg} / \mathrm{kg}(0.78 \%)$ 으로서 가장 높았으며 $\mathrm{P} 877 \mathrm{~F}$ 가 $4,488.4 \mathrm{mg} / \mathrm{kg}(0.45 \%)$ 으로서 가장 낮은 함량을 나타냈다 $(\mathrm{P}<0.01)$. Yang 등 (1989)은 오차드그 라스를 6 7월 수확 시 $\mathrm{K}$ 함량이 평균 $3.20 \%$, 9 10월 수확시 $2.96 \%$ 라고 보고하였으며, Kim (1991)은 가리 비료를 오차드그라스에 $0 \mathrm{~kg} / \mathrm{ha}$ 과 $200 \mathrm{~kg} / \mathrm{ha}$ 를 시용한 결과 가리 $0 \mathrm{~kg}$ 처리구 는 오차드그라스의 $\mathrm{K}$ 함량이 $3 \%$ 미만이었지만, $200 \mathrm{~kg}$ 처리구는 3\% 이상 함유하였다고 보고 하였다. Lee와 Lee (2010)는 옥수수(총체) 파종
시기와 재배기간에 따라 $\mathrm{K}$ 함량이 1,272 2,611 $\mathrm{mg} / \mathrm{kg}$ 이었다고 보고하였다. Han 등 (1983)은 수 단그라스 생육후기에 $\mathrm{K}$ 함량은 $1.14 \%$, 수수는 $1.24 \%$ 라고 하였다. 이들 보고들과 비교해 볼 때, 본 시험에 공시 된 수수 $\times$ 수단그라스 교잡 종의 $\mathrm{K}$ 함량은 오차드그라스 보다는 낮고 옥수 수보다는 높은 것으로 나타났다. $\mathrm{Ca}$ 함량은 Cow pow $>$ Honey chew BMR $>$ G7 $>$ Jumbo $>$ Tubo gold 순으로 높게 나타났으며 $(\mathrm{P}<0.01)$, 품종 간 큰 차이를 보였다. 그리고 $\mathrm{Mg}$ 함량에 서도 $\mathrm{K}$ 와 $\mathrm{Ca}$ 함량이 높았던 Cow pow가 2,237.7 $\mathrm{mg} / \mathrm{kg}$ 로서 가장 높게 나타난 반면, $\mathrm{P} 877 \mathrm{~F}$ 품종 이 가장 낮은 함량 $(649.7 \mathrm{mg} / \mathrm{kg})$ 을 나타냈다 $(\mathrm{P}<0.01)$. 일반적으로 Grass tetany 발생은 목초 중 $\mathrm{Mg}$ 함량이 $0.2 \%$ 이하이고, $\mathrm{K}$ 함량이 $2.5 \%$ 이상 일 때 발생 한다는 보고(Gross, 1973; Grunes 등, 1970; Chun and Chung, 1988)와 비 교할 때 본 실험에 공시 된 수수 $\times$ 수단그라스 품종들의 $\mathrm{Mg}$ 함량은 $0.06 \sim 0.22 \%, \mathrm{~K}$ 함량은 0.33 $\sim 0.83 \%$ 로서 N-P-K 다비 작물이지만 Grass tetany 을 발생시키지 않는 무기물 함량 구조를 가진 것으로 나타났다. $\mathrm{Fe}$ 함량은 Honey chew BMR 이 $139.7 \mathrm{mg} / \mathrm{kg}$ 으로 가장 높았고, $\mathrm{P} 877 \mathrm{~F}$ 가 55.0 $\mathrm{mg} / \mathrm{kg}$ 으로 가장 낮았다 $(\mathrm{P}<0.01)$. 그리고 $\mathrm{Mn}$ 함 량은 Jumbo가 가장 높게 $\mathrm{P} 877 \mathrm{~F}$ 가 가장 낮게 나타났다 $(\mathrm{P}<0.01)$. 본 실험에 공시된 수수 $\times$ 수 
Table 5. The mineral contents of sorghum $\times$ sudangrass hybrids $(\mathrm{mg} / \mathrm{kg})$

\begin{tabular}{lrrrrrrrrr}
\hline & \multicolumn{7}{c}{ Varieties } \\
\cline { 2 - 9 } Items & P877F & Cow pow & $\begin{array}{c}\text { Turbo } \\
\text { gold }\end{array}$ & $\begin{array}{c}\text { Maxi } \\
\text { graze }\end{array}$ & Jumbo & G7 & $\begin{array}{r}\text { Sweet } \\
\text { home }\end{array}$ & $\begin{array}{r}\text { Honey } \\
\text { chew } \\
\text { BMR }\end{array}$ & $\begin{array}{c}\text { Green } \\
\text { star }\end{array}$ \\
\hline $\mathrm{Ca}$ & $1,593.0^{\mathrm{G}}$ & $4,244.9^{\mathrm{A}}$ & $2,411.6^{\mathrm{CD}}$ & $2,285.6^{\mathrm{E}}$ & $2,439.6^{\mathrm{CD}}$ & $2,468.9^{\mathrm{C}}$ & $1,824.3^{\mathrm{F}}$ & $2,687.8^{\mathrm{B}}$ & $1,519.9^{\mathrm{G}}$ \\
$\mathrm{Co}$ & 0.1 & 0.2 & 0.2 & 0.3 & 0.2 & 0.2 & 0.1 & 0.2 & 0.1 \\
$\mathrm{Cu}$ & $2.7^{\mathrm{F}}$ & $2.5^{\mathrm{F}}$ & $3.3^{\mathrm{D}}$ & $4.5^{\mathrm{A}}$ & $3.9^{\mathrm{B}}$ & $3.9^{\mathrm{B}}$ & $3.1^{\mathrm{E}}$ & $3.1^{\mathrm{E}}$ & $3.5^{\mathrm{C}}$ \\
$\mathrm{Fe}$ & $55.0^{\mathrm{E}}$ & $68.6^{\mathrm{D}}$ & $55.1^{\mathrm{E}}$ & $52.0^{\mathrm{F}}$ & $73.3^{\mathrm{C}}$ & $110.2^{\mathrm{B}}$ & $72.5^{\mathrm{C}}$ & $139.7^{\mathrm{A}}$ & $107.9^{\mathrm{B}}$ \\
$\mathrm{K}$ & $4,488.4^{\mathrm{F}}$ & $8,348.0^{\mathrm{A}}$ & $7,796.0^{\mathrm{B}}$ & $4,979.1^{\mathrm{E}}$ & $7,592.6^{\mathrm{B}}$ & $6,486.9^{\mathrm{C}}$ & $3,265.2^{\mathrm{D}}$ & $6,381.9^{\mathrm{C}}$ & $4,674.7^{\mathrm{EF}}$ \\
$\mathrm{Mg}$ & $649.7^{\mathrm{H}}$ & $2,237.7^{\mathrm{A}}$ & $1,203.6^{\mathrm{C}}$ & $944.2^{\mathrm{F}}$ & $986.5^{\mathrm{E}}$ & $1,139.1^{\mathrm{D}}$ & $984.6^{\mathrm{E}}$ & $1,291.7^{\mathrm{B}}$ & $848.5^{\mathrm{G}}$ \\
$\mathrm{Mn}$ & $54.8^{\mathrm{G}}$ & $84.6^{\mathrm{C}}$ & $68.0^{\mathrm{F}}$ & $87.7^{\mathrm{B}}$ & $93.4^{\mathrm{A}}$ & $76.6^{\mathrm{E}}$ & $50.9^{\mathrm{H}}$ & $85.1^{\mathrm{BC}}$ & $82.1^{\mathrm{D}}$ \\
$\mathrm{Mo}$ & 0.1 & 0.1 & $0.1^{\mathrm{B}}$ & 0.1 & 0.1 & 0.0 & 0.0 & 0.1 & 0.1 \\
$\mathrm{Na}$ & $17.3^{\mathrm{E}}$ & $20.0^{\mathrm{D}}$ & $21.1^{\mathrm{C}}$ & $26.3^{\mathrm{B}}$ & $28.2^{\mathrm{A}}$ & $20.0^{\mathrm{D}}$ & $9.5^{\mathrm{G}}$ & $14.2^{\mathrm{F}}$ & $16.5^{\mathrm{E}}$ \\
$\mathrm{Zn}$ & $12.4^{\mathrm{D}}$ & $13.9^{\mathrm{C}}$ & $19.0^{\mathrm{A}}$ & $19.3^{\mathrm{A}}$ & $20.3^{\mathrm{A}}$ & $17.2^{\mathrm{B}}$ & $12.4^{\mathrm{D}}$ & $14.4^{\mathrm{C}}$ & $15.8^{\mathrm{B}}$ \\
$\mathrm{Total}$ & $6,873.5^{\mathrm{D}}$ & $15,020.5^{\mathrm{A}}$ & $11,577.9^{\mathrm{B}}$ & $8,399.1^{\mathrm{CD}}$ & $11,238.1^{\mathrm{B}}$ & $10,323^{\mathrm{BC}}$ & $6,222.6^{\mathrm{D}}$ & $10,618.2^{\mathrm{BC}}$ & $7,269.1^{\mathrm{D}}$ \\
\hline
\end{tabular}

$\mathrm{A}, \mathrm{B}, \mathrm{C}, \mathrm{D}, \mathrm{E}, \mathrm{F}, \mathrm{G}, \mathrm{H}$ Means in the row with difference superscripts different $(\mathrm{P}<0.01)$.

단그라스 교잡종들은 $\mathrm{Na}$ 와 $\mathrm{Zn}$ 함량은 미량 성 분으로, $\mathrm{Co}, \mathrm{Cu}$ 와 $\mathrm{Mo}$ 함량은 극미량 요소로 나타났다. 총 무기물 함량을 보면 $\mathrm{K}, \mathrm{Ca}$ 와 $\mathrm{Mg}$ 함량이 전 무기물 함량의 $95 \%$ 이상을 차지하 며, 이들 성분이 높았던 Cow pow 품종이 $15,020.5 \mathrm{mg} / \mathrm{kg}$ 으로서 가장 높게, 이에 반하여 Sweet home은 $6,222.6 \mathrm{mg} / \mathrm{kg}$ 으로서 가장 낮게 나타났다. 이들 품종 간에는 무려 $8,797.9 \mathrm{mg} / \mathrm{kg}$ 차이를 보이며, 나머지 품종 간에도 큰 차이를 나타냈다. 그러나 Lee와 Lee(2010)가 보고한 사일리지용 옥수수의 무기물 함량이 2,970.8 $\mathrm{mg} / \mathrm{kg} 4,721.25 \mathrm{mg} / \mathrm{kg}$ 이었던 것과 수수 $\times$ 수단 그라스 교잡종의 무기물 함량 $(6,222.6 \mathrm{mg} / \mathrm{kg}$ $\sim 15,020.5 \mathrm{mg} / \mathrm{kg}$ )과 비교 시 수수 $\times$ 수단그라스 교잡종이 월등히 높은 것으로 나타났다.

\section{4. 수수 $\times$ 수단그라스 교잡종의 품종별 구성 아미노산 성분}

품종별 구성아미노산 함량은 Table 6에 나타 내었다. 필수아미노산함량은 품종별 $1,092.3 \mathrm{mg}$ / $100 \mathrm{~g} 1,932.8 \mathrm{mg} / 100 \mathrm{~g}$ 범위로서 Maxi graze가
$1,932.8 \mathrm{mg} / 100 \mathrm{~g}$ 으로 가장 높았던 반면 $\mathrm{P} 877 \mathrm{~F}$ 가 $1,092.3 \mathrm{mg} / 100 \mathrm{~g}$ 으로 가장 낮은 함량을 나 타냈다 $(\mathrm{P}<0.01)$. 나머지 품종에서는 1,226.3 $1,703.8 \mathrm{mg} / 100 \mathrm{~g}$ 의 범위를 나타냈다. 비필수아 미노산 중 Glutamic acid와 Aspartic acid 함량 이 모든 품종에서 높았던 반면 Tyrosine 함량은 낮은 함량을 나타냈다. 총 비필수아미노산 함 량은 Sweet home이 $2,116.9 \mathrm{mg} / 100 \mathrm{~g}$ 으로서 가 장 높은 품종으로 $\mathrm{P} 877 \mathrm{~F}$ 가 가장 낮은 품종으 로 나타났다 $(\mathrm{P}<0.01)$. 총 아미노산 함량은 필수 및 비필수아미노산 함량이 높았던 Maxi graze 가 가장 높은 함량을 나타낸 반면, 필수와 비 필수아미노산 함량이 낮았던 $\mathrm{P} 877 \mathrm{~F}$ 가 가장 낮 은 품종으로 나타났다 $(\mathrm{P}<0.01)$. 필수아미노산 : 비필수아미노산의 비율을 보면 Cow pow 품종 만 $50: 50$ 으로서 필수:비필수 아미노산이 비율 이 같고, 나머지 품종들은 모두 비필수 아미노 산 함량이 높은 것으로 나타났다.

Lee와 Lee (2010)는 옥수수에 있어서 아미노 산 조성은 Glutamic acid > Leucine $>$ proline $>$ Aspartic acid 순으로 높았다고 보고한 내용과 비교 시, 수수 $\times$ 수단그라스 교잡종의 품종들은 
Table 6. The amino acid contents of sorghum $\times$ sudangrass hybrids ( $\mathrm{mg} / 100 \mathrm{~g}$ )

\begin{tabular}{|c|c|c|c|c|c|c|c|c|c|}
\hline \multirow[b]{2}{*}{ Items } & \multicolumn{9}{|c|}{ Varieties } \\
\hline & P877F & Cow pow & $\begin{array}{c}\text { Turbo } \\
\text { gold }\end{array}$ & $\begin{array}{l}\text { Maxi } \\
\text { graze }\end{array}$ & Jumbo & G7 & $\begin{array}{l}\text { Sweet } \\
\text { home }\end{array}$ & $\begin{array}{c}\text { Honey } \\
\text { chew } \\
\text { BMR }\end{array}$ & $\begin{array}{c}\text { Green } \\
\text { star }\end{array}$ \\
\hline Threonine & 91.4 & 119.5 & 161.7 & 189.6 & 149.6 & 145.2 & 160.3 & 139.2 & 100.4 \\
\hline Valine & 210.2 & 236.4 & 291.4 & 313.5 & 233.4 & 214.4 & 271.5 & 227.5 & 223.4 \\
\hline Isoleucine & 101.6 & 269.7 & 168.5 & 196.5 & 135.3 & 108.6 & 121.2 & 103.7 & 98.2 \\
\hline Leucine & 205.3 & 212.7 & 297.4 & 390.6 & 250.5 & 224.3 & 337.6 & 252.5 & 285.5 \\
\hline Phenyalanine & 151.7 & 187.8 & 261.6 & 290.3 & 227.4 & 202.6 & 224.5 & 213.4 & 182.3 \\
\hline Histidine & 51.7 & 64.4 & 91.3 & 104.4 & 73.6 & 65.5 & 79.5 & 65.3 & 55.3 \\
\hline Lysine & 209.8 & 250.8 & 307.2 & 332.5 & 268.5 & 251.6 & 263.5 & 235.7 & 182.6 \\
\hline Arginine & 70.6 & 86.5 & 124.7 & 115.4 & 116.3 & 121.9 & 119.6 & 111.5 & 98.6 \\
\hline Sum of EAA & $1,092.3^{\mathrm{F}}$ & $1,427.8^{\mathrm{CD}}$ & $1,703.8^{\mathrm{B}}$ & $1,932.8^{\mathrm{A}}$ & $1,454.6^{\mathrm{CD}}$ & $1,334.1^{\mathrm{DE}}$ & $1,577.7^{\mathrm{BC}}$ & $1,348.8^{\mathrm{DE}}$ & $1,226.3^{\mathrm{EF}}$ \\
\hline Serine & 88.1 & 116.4 & 163.6 & 184.7 & 168.5 & 162.4 & 193.3 & 164.5 & 123.7 \\
\hline Glutamic acid & 316.7 & 360.7 & 471.7 & 597.7 & 401.5 & 378.6 & 487.3 & 410.7 & 363.7 \\
\hline Proline & 154.8 & 168.1 & 208.4 & 187.3 & 225.1 & 275.4 & 330.2 & 169.6 & 198.4 \\
\hline Glycine & 125.5 & 157.4 & 209.5 & 246.2 & 185.5 & 173.7 & 190.8 & 170.7 & 158.6 \\
\hline Alanine & 174.5 & 217.3 & 284.5 & 302.5 & 256.2 & 237.6 & 260.5 & 231.5 & 211.5 \\
\hline Tyrosine & 24.1 & 34.5 & 58.4 & 67.7 & 52.6 & 46.5 & 92.6 & 79.6 & 66.1 \\
\hline Aspartic acid & 348.7 & 364.5 & 401.9 & 389.3 & 330.7 & 319.2 & 562.2 & 539.5 & 388.7 \\
\hline Sum of NEAA & $1,232.4^{\mathrm{E}}$ & $1,418.9^{\mathrm{DE}}$ & $1,798^{\mathrm{BC}}$ & $1,975.4^{\mathrm{AB}}$ & $1,620.1^{\mathrm{CD}}$ & $1,593.4^{\mathrm{CD}}$ & $2,116.9^{\mathrm{A}}$ & $1,766.1^{\mathrm{BC}}$ & $1,510.7^{\mathrm{D}}$ \\
\hline Total (EAA+NEAA) & $2,324.7^{\mathrm{E}}$ & $2,846.7^{\mathrm{D}}$ & $3,501.8^{\mathrm{ABC}}$ & $3,908.2^{\mathrm{A}}$ & $3,074.7^{\mathrm{CD}}$ & $2,927.5^{\mathrm{D}}$ & $3,694.6^{\mathrm{AB}}$ & $3,114.9^{\mathrm{BCD}}$ & $2,737.0^{\mathrm{DE}}$ \\
\hline EAA: NEAA & $47: 53$ & $50: 50$ & $49: 51$ & $49: 51$ & $47: 53$ & $46: 54$ & $43: 57$ & $43: 57$ & $45: 55$ \\
\hline
\end{tabular}

A, B, C, D, E, F Means in a row with different superscripts are significantly different $(\mathrm{P}<0.01)$.

아미노산 조성 성분비가 품종별로 다양하게 나 타나 일정한 경향치가 나타나지 않았다. 그리고 사료용 알곡 사료 중 옥수수, 보리, 밀, 호밀 및 사일리지용 옥수수의 아미노산 함량은 Glutamic $\mathrm{acid}$ 가 함량이 가장 많이 함유되어 있다고 보고 한 내용(Chiang et al., 1972; Lee and Lee, 2010)과 비교 시, 본 실험에 있어서 수수 $\times$ 수 단그라스 교잡종 식물체 전체를 분석한 구성 아미노산 함량 중에서는 Glutamic acid 함량이 가장 높은 품종과 Aspartic acid 함량이 가장 높은 품종으로 각각 다르게 나타났다.

5. 수수 $\times$ 수단그라스 교잡종의 품종별 영양 소 수량
수수 $\times$ 수단그리스 교잡종의 영양소 수량은 Table 7에서 보는 바와 같이 조단백질 수량은 Turbo gold가 $814.6 \mathrm{~kg} / \mathrm{ha}$ 로 가장 높았고, Cow pow는 $478.2 \mathrm{~kg} / \mathrm{ha}$ 로 가장 낮게 나타났다 $(\mathrm{P}<$ 0.01). 조지방 수량은 Honey chew BMR이 $309.8 \mathrm{~kg} / \mathrm{ha}$ 로서 높은 지방 생산량을 보였고 Turbo gold는 $185.8 \mathrm{~kg} / \mathrm{ha}$ 로 낮은 수량성을 보였 다 $(\mathrm{P}<0.01)$. 광물질 수량은 Cow pow가 가장 높게, Green star가 가장 낮게 나타났다 $(\mathrm{P}<$ 0.01). 아미노산 수량은 Sweet home 이 높게 Green star가 낮게 나타났다 $(\mathrm{P}<0.01) . \mathrm{TDN}$ 수 량은 Sweet home > P877F > Jumbo > G7 > Honey chew BMR $>$ Turbo gold 순으로 높게 나타났다 $(\mathrm{P}<0.01)$. Jeon과 Lee (2005)는 수수 $\times$ 수단그라스 교잡종의 이용회수에 따라 조단백 
Table 7. The nutrition yield of sorghum-sudangrass hybrids $(\mathrm{kg} / \mathrm{ha})$

\begin{tabular}{lcccccccccc}
\hline & \multicolumn{10}{c}{ Varieties } \\
\cline { 2 - 10 } Items & P877F & Cow pow & $\begin{array}{c}\text { Turbo } \\
\text { gold }\end{array}$ & $\begin{array}{c}\text { Maxi } \\
\text { graze }\end{array}$ & Jumbo & G7 & $\begin{array}{c}\text { Sweet } \\
\text { home }\end{array}$ & $\begin{array}{c}\text { Honey } \\
\text { chew } \\
\text { BMR }\end{array}$ & $\begin{array}{c}\text { Green } \\
\text { star }\end{array}$ \\
\hline \hline Crude protein yield & $595.1^{\mathrm{E}}$ & $478.2^{\mathrm{F}}$ & $814.6^{\mathrm{A}}$ & $765.8^{\mathrm{B}}$ & $648.2^{\mathrm{D}}$ & $703.5^{\mathrm{BC}}$ & $753.4^{\mathrm{B}}$ & $663.9^{\mathrm{CD}}$ & $521.6^{\mathrm{F}}$ \\
Crude fat yield & $209.1^{\mathrm{DE}}$ & $191.3^{\mathrm{EF}}$ & $185.8^{\mathrm{F}}$ & $200.3^{\mathrm{EF}}$ & $226.9^{\mathrm{D}}$ & $260.0^{\mathrm{C}}$ & $288.5^{\mathrm{B}}$ & $309.8^{\mathrm{A}}$ & $210.8^{\mathrm{DE}}$ \\
Mineral yield & $111.0^{\mathrm{D}}$ & $207.6^{\mathrm{A}}$ & $165.8^{\mathrm{C}}$ & $99.0^{\mathrm{E}}$ & $181.5^{\mathrm{B}}$ & $157.5^{\mathrm{C}}$ & $99.4^{\mathrm{DE}}$ & $156.4^{\mathrm{C}}$ & $81.0^{\mathrm{F}}$ \\
Amino acid yield & $373.9^{\mathrm{D}}$ & $388.9^{\mathrm{D}}$ & $500.5^{\mathrm{B}}$ & $460.4^{\mathrm{C}}$ & $498.3^{\mathrm{B}}$ & $447.7^{\mathrm{C}}$ & $592.2^{\mathrm{A}}$ & $459.5^{\mathrm{C}}$ & $303.7^{\mathrm{E}}$ \\
TDN yield & $10,181^{\mathrm{A}}$ & $8,430^{\mathrm{C}}$ & $8,807^{\mathrm{C}}$ & $7,516^{\mathrm{D}}$ & $9,804^{\mathrm{A}}$ & $9,283^{\mathrm{B}}$ & $10,194^{\mathrm{A}}$ & $9,220^{\mathrm{B}}$ & $6,880^{\mathrm{E}}$ \\
\hline
\end{tabular}

A, B, C, D, E, F Means in a row with different superscripts are significantly different $(\mathrm{P}<0.01)$.

질 수량은 $1,257 \sim 1,456 \mathrm{~kg} / \mathrm{ha}$ 였다고 보고하였 으며, Jeon 등 (1992)은 2회 예취 시 파종량에 따라 $684.5 \sim 907.1 \mathrm{~kg} / \mathrm{ha}$ 의 조단백질을 생산하였 다고 보고하였다.

$\mathrm{TDN}$ 수량에 있어서 Park과 Kwon(1993)은 예취시기가 Sorghum류 품종의 TDN 수량에 미 치는 영향(3회 예취)에 대한 보고에서 조생종 $15,580 \mathrm{~kg} / \mathrm{ha}$, 중생종은 $9,750 \mathrm{~kg} / \mathrm{ha}$, 만생종은 $7,000 \mathrm{~kg} / \mathrm{ha}$ 로서 숙기가 늦은 품종일수록 TDN 수량은 적었다고 하였다. 그리고 $\mathrm{Kim}$ 등 (2002) 은 수수 $\times$ 수단그라스 교잡종의 수량 실험에서 2회 예취 시 $\mathrm{TDN}$ 수량은 9,871 12,276 kg/ha였 다고 하였다. 그리고 Lee와 Lee (2010)는 논토 양에서 옥수수 파종시기를 5월 1일과 5월 8 일 하였을 때는 TDN수량이 16,176.2 16,699.4 kg/ha 였으며, 5월 15일, 5월 22일 및 5월 29일 파종 시에는 $10,838.3 \sim 11,025.2 \mathrm{~kg} / \mathrm{ha}$ 였다고 보고하 였다. 이상의 보고 내용과 본 시험 결과를 비 교해 보면, 논토양에서 수수x수단그리스 교잡 종을 1회 예취를 목표로 숙기를 연장하여 수확 하는 것은 (105일 재배) 3 회 예취하는 것에 비 하여 단백질 수량은 떨어진다. 그러나 $\mathrm{TDN}$ 수 량에 있어서는 수수 $\times$ 수단그라스 교잡종의 만 생종 보다 $\mathrm{TDN}$ 수량이 높고, 5월 중순 이후 파종시기가 늦은 사일리지용 옥수수의 $\mathrm{ha}$ 당 $\mathrm{TDN}$ 수량과 비슷한 것으로 나타났다.
IV. 요 약

본 시험은 수수 $\times$ 수단그라스 교잡종 논토양 재배 시 품종별 생육특성 및 사료적 가치를 규 명하기 위하여 실시하였으며, 공시재료는 추천 품종 9품종을 공시하였다. 초장, 엽수, 경의 굵 기 및 경경도에 있어서는 Jumbo가 다른 품종 에 비하여 유의적으로 높은 수치를 나타냈다 $(\mathrm{P}<0.01)$. 당도는 $\mathrm{P} 877 \mathrm{~F}>$ Sweet home $>$ Maxi graze $>$ Green star $>$ Cow pow $>$ G7 순으로 높게 나타났으며, 생초수량과 건물수량에 있어 서는 생육특성이 좋았던 Jumbo 품종이 각각 $86,199 \mathrm{~kg} / \mathrm{ha}$ 및 $16,206 \mathrm{~kg} / \mathrm{ha}$ 으로 다른 품종에 비하여 가장 높은 수량성을 보였다 $(\mathrm{P}<0.01)$. 조 단백질 함량은 Maxi graze가 $6.5 \%$ 로 가장 높 게, 조지방 함량은 Honey chew BMR이 2.1\%로 가장 높게 나타났다 $(\mathrm{P}<0.01)$. 그리고 Jumbo와 $\mathrm{G} 7$ 품종은 $\mathrm{NDF}$ 및 $\mathrm{ADF}$ 함량이 높은 품종으 로 나타났다 $(\mathrm{P}<0.01) . \mathrm{TDN}$ 함량은 품종 간에 유의적인 차이를 보이지 않았다. 무기물 함량 은 Cow pow $>$ Turbo gold $>$ Jumbo $>$ Honey chew BMR > G7 순으로 높게 나타났으며, 총 구성 아미노산 함량은 Maxi graze > Sweet home $>$ Turbo gold $>$ Honey chew BMR $>$ Jumbo 순으로 높게 나타났다. 단백질 생산량 및 지방 생산량은 각각 Turbo gold $(814.6 \mathrm{~kg} / \mathrm{ha})$ 
및 Honey chew BMR $(309.8 \mathrm{~kg} / \mathrm{ha})$ 이 가장 높게 나타났으며 $(\mathrm{P}<0.01)$, 광물질 생산량은 $\mathrm{Cow}$ pow 품종이 $207.6 \mathrm{~kg} / \mathrm{ha}$ 로서 높게 나타났다 $(\mathrm{P}<0.01)$. 구성 아미노산 생산량과 TDN 생산량 은 Sweet home 품종이 각각 $592.2 \mathrm{~kg} / \mathrm{ha}$ 및 $10,194 \mathrm{~kg} / \mathrm{ha}$ 로 가장 높게 나타났다 $(\mathrm{P}<0.01)$. 이 상 결과를 종합해 보면 수수 $\times$ 수단그라스 교잡 종을 논토양에서 재배 시 생육특성 및 각종 영 양수량이 다양하게 나타남으로서 품종 선택은 이용 목적에 따라 선택 재배하는 것이 바람직 할 것으로 생각된다.

$$
\mathrm{V} \text {. 사 사 }
$$

본 연구는 2009년도 상주시 신활력사업 지원 사업에 의하여 이루어진 것이며, 이의 지원에 감사드립니다.

\section{VI. 인 용 문 헌}

1. AOAC. 1995. Official Methods of analysis. 16th ed. Association of analytical chemist, Washington, DC., USA.

2. Chiang, Y.H., C.Y. Lee, S.C. Kim, C.W. Lee, K. S. Kim and C.Y. Yoon. 1972. Studies on amino acids in feed stuffs. I. Amino acids contents in several concentrates including yellow corn. Kor. J. Anim. Sci. 14(3):224-229.

3. Chun, W.B. and K.C. Choi and K.H. Kim. 1995. Comparison of Sorghum-Sudangrass hybrids for feeding value and forage production in Chonnam region. J. Kor. Grassl. Sci. 15(1):67-72.

4. Chun, W.B. and W.T. Chung. 1988. studies on productivity and cutting management in orchardgrass pasture. IV. Mineral contents and grass tetany hazard of grass in mountain pasture. Kor. J. Anim. Sci. 30(6):370-374

5. Goering, H.K. and P.J. Van Soest, 1970. Forage fiber analysis. Ag. Handbook. No. 379. ARS. USDA. washington DC.

6. Gross, C. 1973. Managing Mg-deficient soils to prevent grass tetany. Proc. meet. soil conserv. Soc. Am., Hot Springs, Ark., Oct. 1.
7. Grunes, D.L., P.R. Stout and J.R. Brownell. 1970. Grass tetany of ruminants Advance in Agronomy. 22:331-374.

8. Han, H.J., B.H. Park and S.B. Ahn. 1984. Relationship among yield components of forage Sorghum with different fertilizer levels and plant densities. Kor. J. Anim. Sci. 26(5):483-488.

9. Han, I.K., Y.H. Jang, L.E. Harris, L.C. Kearl, P.V. Fonnesbeck. 1983. Hand book of nutrition. feed grassland. AJAS. pp 140-141.

10. Jeon, B.T. and S.M. Lee. 2005. Effect of cutting times according to growth Sorghum $\times$ Sudangrass hybrid on frequence of use, growth characteristics, forage production and crude protein yield. J. Kor. Grassal. Sci. 25(1):33-42.

11. Jeon, B.T., S.M. Lee, D.U. Shin, S.H. Moon and U.S. Kim. 1992. Effect of plant density and planting pattern on the growth characteristics, dry matter yield and feeding value of SorghumSudangrass hybrid. J. Kor. Grassal. Sci. 12(1):49-58.

12. Jeon, B.T., S.M. Lee, S.H. Moon and S.W. Kim. 1989. Studies on the productivity and adaptability of introduced Sorghum $\times$ Sudangrass hybrids in Jungweon and Chungju area. J. Kor. Kon Kuk Uni. Jungweon Institute. 8:143-153.

13. Ji, H.C., S.H. Lee, S.H. Yoon, O.D. Kwon, G.J. Choi, W.H. Kim and K.Y. Kim and Y.C. Lim. 2010. Growth, forage production and quality of sorghum, Sorghum $\times$ Sudangrass and Sudangrass hybrids at paddy field in southern region of Korea. J. Kor. Grassal. Sci. 30(2):109-114.

14. Kim, D.A., J.R. Kim, C.H. Kwon, W.H. Kim and J.K. Kim. 1991. Performance of Sudangrass, Sudangrass hybrids and Sorghum-Sudangrass hybrid for forage production. V. Comparison of recommended cultivars of Sorghum-Sudangrass hybrids. J. Kor. Grassal. Sci. 11(4):258-263.

15. Kim, D.A., U.B. Chun, C.N. Shin, J.G. Kim, D. E. Shin, W.H. Kim and J.K. Kim. 1998. Evaluation of the government recommended forage cultivars in Korea. IV. Forage performance and quality of Sorghum-Sudangrass hybrids. J. Kor. Grassal. Sci. 18(1):1-10.

16. Kim, J.D., C.H. kwon, H.J. Kim, J.G. Park, B.S. Lee, G.S. Bing and S.T. Moon. 2002. Comparison of agronomic characteristics, forage yield and 
quality of Sorghum $\times$ Sudangrass hybrid. J. Kor. Grassal. Sci. 22(4):297-302.

17. Kim, M.C. 1991. Effects of nitrogen and potassium application on pasture of Cheju volcanic soil. I. Dry matter yield and mineral concentration $(\mathrm{N}, \mathrm{P}$, k, Ca, Ma, Na) of Orchardgrass. Kor. J. Anim. Sci. 33(9):683-691.

18. Kim, U.D., S.M. Lee and J.H. Hwang. 2009. Effects of collection time on physical characteristic and nutritive value of rice straw. J. Kor. Grassal. Sci. 29(3):217-226.

19. Lee, J.K., J.G. Kim, D.E. Shin, S.H. Yoon, W. H. Kim, S. Seo and G.J. Park. 2000. Effects of cutting frequency on yield and nutritive value between heading and headless varieties of Sorghum $\times$ Sudangrass hybrid. J. Kor. Grassal. Sci. 20(4):237- 242.

20. Lee, S.M. 2005a. Effect of the cultivation method and cutting time on the growth characteristics, dry matter yield and voluntary intake in Sorghum $\times$ Sudangrass hybrid. J. Kor. Grassal. Sci. 25(1): 7-16.

21. Lee, S.M. 2005b. Effect of inter-croppig on the growth characteristics, yield and palatability of Sorghum $\times$ Sudangrass hybrid in 1st, 2nd and 3rd cutting time. J. Kor. Grassal. Sci. 25(1):23-32.

22. Lee, S.M. and J.H. Lee. 2010. Effects of seeding dates and growth periods on the growth characteristics dry matter yield and feed value of corn for silage in paddy field. J. Kor. Anim. Sci. \& Techno. 52(5):441-448.

23. Lee, S.M., J.B. Tae and J.Y. Koo. 1994. Comparison of agronomic characteristics and productivity of Sorghum $\times$ Sudangrass hybrids. J. Kor. Grassal. Sci. 14(1):34-41.

24. Lee, S.M., S.H. Moon, J.Y. Koo and B.T. Jeon. 1992. Effect of cutting height and nitrogen fertilization levels on the growth characteristics and dry matter yield of Sorghum-Sudangrass hybrid. J. Kor. Grassal. Sci. 12(1):41-48.

25. Lee. S.S. and S.J. Choi. 1990. Forage productivity of corn and Sorghum hybrids in rice blackstreaked dwarf virus prevalent area. J. Kor.
Grassal. Sci. 10(1):42-47.

26. Lee, S.S., S.J. Choi and T.J. Kim. 1991. Forage productivity of two Sorghum and a SorghumSudangrass hybrids harvested at different growth stages. J. Kor. Grassal. Sci. 11(2):121-128.

27. Lim, Y.C., S.H. Yoon, W.H. Kim, J.G. Kim, J. S. Shin, M.W. Jung, S. Seo and W.B. Yook. 2006. Effects of livestock manure application on growth characteristics, yield and feed value of Sorghum-Sudangrass hybrid and $\mathrm{NO}_{3}-\mathrm{N}$ leaching in paddy field. J. Kor. Grassal. Sci. 26(4):233238.

28. Park, B.H. and S.W. Kwon. 1993. Effect of different defoliation on dry matter and TDN yield of Sorghum cultivars. J. Kor. Grassal. Sci. 13(2): 132-138.

29. RDA. 2003. Agricultural research based on the test. Kor. Rural development administration.

30. SAS. 2002. SAS user's guide; Statistics. SAS Inst. Inc. $\mathrm{NC}$

31. Seo S. and D.A. Kim. 1985. Effect of nitrogen and cutting height on the appearance and dry weight of new bud, and yield of forage SorghumSudangrass hybrid. Kor. J. Anim. Sci. 27(5):328332.

32. Shin, J.S., S.H. Lee, W.H. Kim, J.G. Kim, S.H. Yoon and K.B. Lim. 2005. Effects of ammouium sulfate and potassium sulfate fertilizer on dry matter yield and forage quality of Sorghum $x$ Sudangrass hybrid in reclaimed tidal land. J. Kor. Grassal. Sci. 25(4):245-250.

33. Smith, A.E. 1972. Amethod for quantifying carbohydrate fraction in forage plants. Agric. food Chem. 20:238-239.

34. Yang. K.C., C.C. Choung, K.I. Kim and M.C. Kim. 1989. Organic nitrogen, and mineral contents in soil, forage, blood serum of beef cattle sampled in June-July or September-October from pastures of Cheju island. J. Kor. Grassal. Sci. 31(4):261-270.

(Received January 17, 2012/Accepted February 29, 2012) 